\title{
Transfer of beta-lactamase plasmids by conjugation in Neisseria gonorrhoeae
}

\author{
C A Ison, M J Gill, N Woodford
}

\begin{abstract}
Conjugation experiments in vitro have been used in an attempt to explain certain epidemiological phenomena seen amongst penicillinase producing Neisseria gonorrhoeae (PPNG) isolated at St Mary's Hospital, London. These include changes in plasmid profiles, a lack of beta-lactamase encoding plasmids in PAOU-requiring strains and a difference in the serological classification of strains of PPNG and non-PPNG isolated from the same clinic. It was shown that acquisition of the conjugative plasmid by beta-lactamase producing transconjugants does vary, but is not related to the auxotype/serovar (A/S) class of, or type of beta-lactamase plasmid carried by the donor. It was not possible to transfer either the 3.2MDa or $4.4 \mathrm{MDa}$ plasmids to PAOU-requiring strains of $\boldsymbol{N}$ gonorrhoeae. The conjugation frequency from a single donor to different recipients was shown to be variable, but was not influenced by the serovar of the recipients. It was shown that the transfer and acceptance of beta-lactamase encoding plasmids is variable but it was not possible to identify the factors responsible.
\end{abstract}

\section{Introduction}

Penicillinase-producing strains of Neisseria gonorrhoeae (PPNG) were first isolated in $1976 .{ }^{1-4}$ Strains of PPNG isolated in the United Kingdom and linked epidemiologically to West Africa ${ }^{12}$ were reported to carry a 3.2 megadalton ( $\mathrm{MDa}$ ) beta-lactamase encoding plasmid. ${ }^{5}$ Strains found originally in the USA, ${ }^{34}$ but linked to the Far East, were found to carry a 4.4 MDa plasmid. ${ }^{5}$ Initially, only these latter strains contained a $24.5 \mathrm{MDa}$ "conjugative" plasmid, but it has now also been found in strains carrying the $3.2 \mathrm{MDa}$ plasmid. ${ }^{6}$ The conjugative plasmid is capable of self-transfer and is essential for mobilisation of beta-lactamase plasmids between

Department of Medical Microbiology, St Mary's Hospital Medical School, London W2 1PG, UK C A Ison, M J Gill, N Woodford gonococci. ${ }^{7}$ More recently other beta-lactamase plasmids have also been reported ${ }^{8-11}$ but these plasmids have not yet become widely distributed.

Strains of PPNG carrying the $3.2 \mathrm{MDa}$ or 4.4 $\mathrm{MDa}$ plasmids have become established in the United Kingdom. ${ }^{12}$ Since 1978 we have monitored the strains of PPNG isolated at St Mary's Hospital, London ${ }^{1314}$ and have noticed three interesting phenomena. Firstly there have been changes in plasmid profiles. The proportion of PPNG with the 3.2 MDa plasmid decreased between 1979 and 1985, while those with the $4.4 \mathrm{MDa}$ plasmid increased. However, the proportion of strains carrying both the 4.4 $\mathrm{MDa}$ plasmid and the conjugative plasmid decreased. Secondly we have never detected betalactamase plasmids in proline, arginine and uracil requiring strains, which do not utilise ornithine (PAOU-requiring). Finally, we have found that the commonest serovars among our PPNG are IB-1 and IB-5/7. ${ }^{14}$ This contrasts with the non-PPNG where serovars IB-1, IB-2, IB-3 and IA-2 predominate. ${ }^{15}$ To explain these findings, we have investigated plasmid transfer by conjugation in vitro.

\section{Methods \\ STRAINS}

Isolates of $N$ gonorrhoeae were identified by Gram stain, oxidase reaction, and the utilisation of glucose, but not of maltose, sucrose or lactose. Penicillinase production was detected with Nitrocefin (Oxoid). ${ }^{16}$

The following donor strains were all PPNG isolated at St Mary's Hospital, London. Eleven strains of PPNG carrying either the 3.2 MDa or 4.4 $\mathrm{MDa}$ beta-lactamase encoding plasmids and belonging to different auxotype/serovar (A/S) classes were used in experiments to investigate the acquisition of the conjugative plasmid by transconjugants (table 1 ). Nine of these strains also carried the $24.5 \mathrm{MDa}$ conjugative plasmid. Two of these strains, 661 and 760 , were also used as donors in experiments with PAOU-requiring recipients. A single PPNG strain isolated in London, but originating from the Far East, carrying both a $4.4 \mathrm{MDa}$ beta-lactamase and a $24.5 \mathrm{MDa}$ conjugative plasmid and belonging to $\mathrm{A} / \mathrm{S}$ class Proto/IA-6, was used as donor to investigate the effect of the serovar of the recipient on the conjugation frequency. 
Table 1 Acquisition of the conjugative plasmid by beta-lactamase producing transconjugants

\begin{tabular}{|c|c|c|c|c|}
\hline $\begin{array}{l}\text { Donor } \\
\text { strain }\end{array}$ & $\begin{array}{l}\text { Donor } \\
\text { auxotype/serovar } \\
\text { class }\end{array}$ & $\begin{array}{l}\text { Donor } \\
\text { plasmids } \\
(M D a)\end{array}$ & $\begin{array}{l}\text { Recipient } \\
\text { strain } \dagger\end{array}$ & $\begin{array}{l}\text { Transconjugants } \\
\text { with } 24.5 \mathrm{MDa} \\
\text { plasmid } \\
\% \text { (No/No tested) }\end{array}$ \\
\hline $\begin{array}{r}66 \\
61 \\
627 \\
661 \\
733 \\
841 \\
\end{array}$ & $\begin{array}{l}\text { Pro/IA-2 } \\
\text { Pro/IA-4 } \\
\text { Proto/IB-7 } \\
\text { Pro/IB-1 } \\
\text { Pro/IB-7 } \\
\text { Pro/IB-1 }\end{array}$ & $\begin{array}{l}4.4 \\
4.4,24.5 \\
4.4,24.5 \\
4.4,24.5 \\
4.4,24.5 \\
4.4,24.5\end{array}$ & $\begin{array}{l}\text { H1-7 } \\
\text { H1-7 } \\
\text { H1-7 } \\
\text { R1 } \\
\text { R1 } \\
\text { R1 }\end{array}$ & $\begin{array}{l}0(0) \\
74.4(29 / 39) \\
60 \cdot 8(31 / 51) \\
70 \cdot 0(28 / 40) \\
36.0(17 / 50) \\
76 \cdot 0(38 / 50)\end{array}$ \\
\hline $\begin{array}{l}785 \\
728 \\
771 \\
601 \\
760\end{array}$ & $\begin{array}{l}\text { Pro/IA-2 } \\
\text { Met/IA-4 } \\
\text { Arg/IB-3 } \\
\text { Proto/IA-4 } \\
\text { Pro/IB-3 }\end{array}$ & $\begin{array}{l}3.2 \\
3.2,24.5 \\
3.2,24.5 \\
3.2,24.5 \\
3.2,24.5\end{array}$ & $\begin{array}{l}\mathbf{H} 1-7 \\
\mathbf{H} 1-7 \\
\mathbf{H} 1-7 \\
\mathbf{R} 1 \\
\text { R1 }\end{array}$ & $\begin{array}{l}0(0) \\
90.5(38 / 42) \\
76.9(30 / 39) \\
68 \cdot 3(28 / 41) \\
76.9(30 / 39)\end{array}$ \\
\hline
\end{tabular}

^All strains carried 2.6 MDa plasmid.

Pro = proline requiring; Proto $=$ prototrophic or non-requiring; $\mathrm{Arg}=$ arginine requiring; Met $=$ methionine requiring.

$\dagger \mathrm{H1-7}=$ Streptomycin resistant transformant

R1 = Rifampicin resistant mutant.

Recipient strains were antibiotic resistant mutants of laboratory and clinical strains of $N$ gonorrhoeae. A spontaneous rifampicin-resistant mutant $(\mathrm{R}-1)$ of a laboratory strain $(\mathrm{HI})$ was obtained by inoculating GC agar base containing $100 \mathrm{mg} / 1$ rifampicin, with a heavy suspension of organisms and incubating for 48 hours. In addition, a streptomycin-resistant derivative $(\mathrm{H} 1-7)$ of strain $\mathrm{H} 1$ was constructed in transformation experiments with DNA from a streptomycin resistant clinical isolate. Both these strains were used as recipients to investigate their ability to acquire the conjugative plasmid in addition to the beta-lactamase plasmids. Further rifampicin resistant mutants were obtained from either PAOUrequiring clinical isolates which carried no plasmids (three strains) or from isolates of non-PPNG of differing serovars (table 2 ).

\section{SEROTYPING}

Serotyping was performed by co-agglutination of boiled suspensions of gonococci with a panel of 12 monoclonal antibodies to Protein I. ${ }^{17} 18$ Agglutination patterns were used to classify isolates into serovars using the nomenclature of Knapp et al. ${ }^{18}$

\section{AUXOTYPING}

The nutritional requirements of isolates were determined on the defined media of Copley and Egglestone. ${ }^{19}$ The presence or absence of growth was noted after 24 hours incubation at $37^{\circ} \mathrm{C}$ in a $5 \%$ carbon dioxide atmosphere.

\section{CONJUGATION PROCEDURE}

Suspensions of conjugation donor and recipient were made in proteose peptone (Difco) and adjusted to an optical density of 1.0 at $540 \mathrm{~nm}$. The donor suspension was diluted 1:10 for use. The viable count of the recipient (approximately $10^{8}$ colony-forming units/ $\mathrm{ml}$ ) was determined by serial dilutions. DNase I (from bovine pancreas; Sigma) was added to a final concentration of $0.1 \mathrm{mg} / \mathrm{ml}$ to each of the donor and recipient suspensions. A $25 \mathrm{~mm}$ diameter celluloseacetate filter (pore size $0.45 \mu \mathrm{m}$; Nucleopore Corp) was placed on a fresh plate of GC agar base. Onto the filter were placed $100 \mu \mathrm{l}$ each of the donor and recipient suspensions and $100 \mu \mathrm{l}$ of DNase I $(1 \mathrm{mg} /$ $\mathrm{ml}$ ). This gave a donor:recipient ratio of 1:10. The plate was incubated at $37^{\circ} \mathrm{C}$ in $5 \%$ carbon dioxide. After 2 hours incubation a further $100 \mu \mathrm{l}$ of DNase I $(1 \mathrm{mg} / \mathrm{ml})$ was added and the plates reincubated.

After a total of 4 hours incubation the celluloseacetate filter was carefully removed from the plate, placed in $1 \mathrm{ml}$ of saline and vortexed vigorously to disrupt conjugation. Transconjugants were detected by plating aliquots of the resultant cell suspension onto selective medium containing either rifampicin

Table 2 The effect of Protein I serovar of the recipient strain on conjugation frequency

\begin{tabular}{lll}
\hline $\begin{array}{l}\text { Recipient } \\
\text { strain }\end{array}$ & Serovar & $\begin{array}{l}\text { Conjugation } \\
\text { frequency }\end{array}$ \\
\hline R156 & IA-2 & $3.6 \times 10^{-6}$ \\
R256 & IA-2 & $1.5 \times 10^{-5}$ \\
R234 & ND-1 & $1 \cdot 2 \times 10^{-6}$ \\
R76 & IB-1 & $1.6 \times 10^{-4}$ \\
R172 & IB-2 & $2.5 \times 10^{-4}$ \\
R248 & IB-2 & ND \\
R269 & IB-3 & $2 \cdot 4 \times 10^{-5}$ \\
R279 & IB-3 & ND \\
R70 & ND & $30^{-3}$ \\
R142 & IB-3 & $2.4 \times 10^{-5}$ \\
R197 & IB-5 & $4.1 \times 10^{-6}$ \\
\hline
\end{tabular}

*Number of transconjugants per input recipient.

ND = transconjugants not detected in two experiments, that is, < $10^{-7}$ /input recipient. 
(50 mg/l; Sigma) or streptomycin $(150 \mathrm{mg} / \mathrm{l})$ and penicillin $(4 \times \mathrm{MIC}, 0.12 \mathrm{mg} / \mathrm{l}$ unless otherwise stated, Adatabs, Mast Laboratories). The selective media were incubated for three days. Betalactamase-producing transconjugants were identified by overlaying selective plates with filter paper (Whatman No 1) soaked in Nitrocefin (Oxoid). As negative controls, donor and recipient strains were also plated onto these media and incubated for the same time.

The frequency of conjugation was expressed as the number of transconjugants obtained per recipient cell exposed to donor cells (that is "input" recipient).

\section{PLASMID ANALYSIS}

Transconjugants were sub-cultured once on selective medium and once on plates containing $1 \mathrm{mg} / \mathrm{l}$ penicillin before plasmid analysis. Plasmids were extracted by the rapid alkaline lysis method of Birnboim and Doly. ${ }^{20}$ Electrophoresis was performed in a $0.9 \%$ agarose gel. The plasmids were visualised by ethidium bromide staining and ultraviolet light transillumination of the gel. For each donor/recipient combination studied approximately 40 transconjugants, obtained from two individual experiments, were analysed for the presence of betalactamase and conjugative plasmids.

\section{STATISTICAL ANALYSIS}

Differences between the acquisition of the conjugative plasmid from PPNG carrying either the 3.2 $\mathrm{MDa}$ or $4.4 \mathrm{MDa}$ beta-lactamase plasmid were determined using the chi square test. Differences between the conjugation frequencies to recipients of different serovars from a single donor were determined using the unpaired Student's $t$ test.

\section{Results}

ACQUISITION OF THE CONJUGATIVE PLASMID

The streptomycin resistant $(\mathrm{H} 1-7)$ and rifampicin resistant (R-1) mutants were used as recipients in conjugation experiments to determine the frequency of acquisition of the conjugative plasmid by transconjugants that had acquired beta-lactamase plasmids. Two donor strains which carried a betalactamase plasmid of 4.4 and $3.2 \mathrm{MDa}$ respectively, but no conjugative plasmid, produced no transconjugants (conjugation frequency $<10^{-7}$ per input recipient) with either mating (table 1 ). This result confirmed that the conjugative plasmid was necessary for mobilisation of beta-lactamase plasmids as described previously. ${ }^{\text {? }}$

A strain which was partially isogenic with the recipients, but carried both a beta-lactamase (3.2 $\mathrm{MDa}$ ) and conjugative plasmid was also used as a donor. All 40 beta-lactamase producing transconjugants tested possessed the conjugative plasmid. When clinical strains of PPNG which possessed both conjugative and beta-lactamase plasmids were used as donors between $36-90.5 \%$ of transconjugants which expressed beta-lactamase also carried the conjugative plasmid (table 1). The frequency of acquisition of the conjugative plasmid from donors with the 4.4 MDa plasmid was lower than from those with the 3.2 MDa plasmid $(p=0.01)$. However, the difference was related to the low number of transconjugants accepting the conjugative plasmid from strain 733 . If this strain was eliminated from the analysis the difference was less significant $(p=0.03)$. In view of the small numbers tested we feel this low level of significance may be misleading.

\section{PAOU-REQUIRING STRAINS AS RECIPIENTS}

Three PAOU-requiring strains with MICs to penicillin of $0.5 \mathrm{mg} / 1$ were used as recipients. These were mated with two donor strains, 661 and 760 , which carried the 4.4 and 3.2 MDa plasmids respectively together with the conjugative plasmid.

Transconjugants were selected on media containing rifampicin $(100 \mathrm{mg} / \mathrm{l})$ and penicillin at either 2 $\mathrm{mg} / 1$ ( $4 \times \mathrm{MIC}$ of the recipient strains) $0.5 \mathrm{mg} / \mathrm{l}$ or $0 \cdot 12 \mathrm{mg} / 1$. The two highest concentrations of penicillin suppressed growth of both donor and recipient strains, but no beta-lactamase producing transconjugants were detected. As the frequency at which the transconjugants are detected is influenced by the level of penicillin in the selective medium, we used the growth from the $0.12 \mathrm{mg} / 1$ selection to detect transconjugants. This medium did not suppress growth of the recipient and so any transconjugants would have been masked. Therefore the growth from this medium was suspended in saline, diluted and subcultured onto media containing rifampicin (50 $\mathrm{mg} / \mathrm{l})$ and penicillin $(1 \mathrm{mg} / \mathrm{l})$. A single transconjugant colony on the original selective medium should give rise to many colonies on this second selection which completely inhibited the recipient. No transconjugants were detected after this additional step.

EFFECT OF SEROVAR OF THE RECIPIENT ON CONJUGATION FREQUENCY

We used rifampicin resistant mutants of strains belonging to serovars common in our collection of non-PPNG (IA-2, IB-1, IB-2, IB-3, IB-5 and IB-7) as recipients in conjugation experiments. A single donor was used, which had been isolated in the UK, but was acquired in the Far East and carried the 4.4 $\mathrm{MDa}$ and 24.5 MDa plasmids. We found considerable variation in the conjugation frequency and identified three strains in which we could not detect transconjugants. A fourth strain produced no transconjugants when first tested but a second experiment did yield beta-lactamase producing transconjugants. This is probably within the limits of experimental error of this technique. The conjugation frequencies obtained with eleven recipient strains are shown in 
table 2. No significant differences were found between the ability of strains of most of the serovars to act as recipients $(p>0 \cdot 1)$ except for between strains of serovar IA-2 and IB-1 $(p=0 \cdot 002)$. Only one strain belonging to serovar IB-1 was tested, so these results should be interpreted with caution.

\section{Discussion}

\section{ESTABLISHMENT OF THE METHOD}

We have used conjugation experiments to examine the transfer of plasmids between gonococci in vitro. We have used the method of Genco et al ${ }^{21}$ and have selected transconjugants using penicillin at a concentration of four times the MIC of most of the recipients, that is, $0.12 \mathrm{mg} / \mathrm{l}$. Higher concentrations of penicillin were used only where PAOU-requiring strains acted as recipients. Under these conditions we found large numbers of colonies of the recipient, in addition to beta-lactamase producing transconjugants, appeared on the selective medium. This is probably the result of the penicillin degradation in the medium. Such degradation may be caused by the release of beta-lactamase during lysis of the donor when sub-cultured on media containing antibiotics to which it is sensitive (rifampicin or streptomycin). We overcame this problem by identifying transconjugants with filter paper soaked in Nitrocefin which was laid onto the medium. Eisenstein et al ${ }^{22}$ encountered similar problems and identified their transconjugants only after several transfers by replica plating onto antibiotic-containing media. We did not use higher concentrations of penicillin to prevent growth of the recipient because we have found the conjugation frequency was reduced, as has been reported previously. ${ }^{23}$

\section{CHANGES IN PLASMID PROFILES}

Firstly, we used conjugation to examine the acquisition of the conjugative plasmid in addition to betalactamase plasmids. We had noticed an increase in strains without the conjugative plasmid in our population of PPNG isolated from patients attending St Mary's Hospital between 1983-85..$^{1314}$ Our epidemiological data suggested that the majority of the infections were acquired in the United Kingdom. We postulated that gonococci indigenous to the UK had now acquired beta-lactamase plasmids in vivo. However, this theory was not supported by the absence of the conjugative plasmid, which is necessary for mobilisation of beta-lactamase plasmids into new strains of gonococci, in PPNG isolated at that time.

Our results, in vitro, showed that when partially isogenic strains were used as donor and recipient, all beta-lactamase producing transconjugants also acquired the conjugative plasmid after a four hour incubation. This is contrary to the findings of
Roberts et $a l^{7}$ who found that transfer of the conjugative plasmid into beta-lactamase producing transconjugants needed overnight incubation. We investigated the ability of the same recipient to accept plasmids from donors that were clinical isolates belonging to different $\mathrm{A} / \mathrm{S}$ classes. The serovar of a strain of $\mathrm{Ngonorrhoeae}$ is determined by the presence of different epitopes on the major outer membrane protein, PI. This protein is a porin and accounts for $60 \%$ of the cell envelope. ${ }^{24}$ The serovar is often used in conjunction with the auxotype to give greater phenotypic discrimination between strains. ${ }^{25}$ The variation seen in the ability of this recipient to accept the conjugative plasmid in addition to the betalactamase plasmid (table 1) could not be attributed to either the A/S class of, or the presence of different beta-lactamase plasmids in the donor. Only when strain 733 was used as donor was the number of transconjugants with the conjugative plasmid significantly lower. It appears from the small number of strains tested in this study that, when clinical strains are used as donors, the frequency of plasmid transfer does vary. However, this appears unrelated to either the $\mathrm{A} / \mathrm{S}$ class or size of the plasmid of the donor. It is more probable that factor(s) associated with the outer membrane, other than its serovar, are involved in mating pair formation and/or in the uptake of plasmids by the recipient.

\section{ACQUISITION OF PLASMIDS BY PAOU-REQUIRING STRAINS}

PAOU-requiring strains have been reported not to carry the cryptic plasmid of $2.6 \mathrm{MDa}^{26}$ which is found in more than $95 \%$ of other gonococci. ${ }^{27}$ We have been unable to mobilise either the $3.2 \mathrm{MDa}$ or $4.4 \mathrm{MDa}$ plasmid into three such strains in conjugation experiments in vitro. Mavrommati and Tzelepi ${ }^{28}$ have shown that a beta-lactamase plasmid can be accepted by a single PAOU-requiring strain. However, transfer of the beta-lactamase plasmid was not achieved directly between two clinical isolates, but via a laboratory adapted strain (WHO control strain A). If surface phenomena play a part in transfer of plasmids during conjugation, it is possible that these experiments were successful because of changes which had occurred in the cell envelope of strain WHO A during multiple subculture over the years. To our knowledge there are no reports of successful transfer of beta-lactamase plasmids to PAOUrequiring clinical isolates. Interestingly, none of the beta-lactamase producing transconjugants obtained by Mavrommati and Tzelepi ${ }^{28}$ carried the cryptic plasmid. It is possible that PAOU-requiring strains the cryptic plasmid is either integrated into the chromosome ${ }^{29}$ or cannot be accepted. All strains in our collection of over 1000 PPNG possess the cryptic plasmid and none are PAOU-requiring. We feel that these facts, together with our inability to transfer 
beta-lactamase encoding plasmids into PAOUrequiring strains in vitro suggests that the cryptic plasmid may influence the uptake of other plasmids. The cryptic plasmid is known to code for ten proteins but their functions remain unknown. ${ }^{30}$ It is possible that one of these proteins is directly involved in conjugation.

\section{SEROVAR OF THE RECIPIENT}

We have also used conjugation to investigate the effect of the serovar of the recipient on the frequency of transfer of beta-lactamase plasmids. We have tested for transconjugants four hours after mixing donor and recipient. The differences we have detected between strains and between experiments with the same strain may be a reflection of differences in the rate of acquisition. Sarafian et al $^{31}$ have used a 16 hour incubation at which time uptake is probably complete. Our PPNG population isolated at St Mary's Hospital is restricted to relatively few serovars and differs considerably from our strains of non-PPNG. Serovars IB-2 and IB-3 appear infrequently amongst our PPNG. ${ }^{14}$ Our results in vitro suggest that there may be some strain variation in the ability to acquire beta-lactamase plasmids but there is little evidence that it is related to the serovar and hence to Protein I.

We have tried to use conjugation experiments in vitro to help explain the epidemiology of PPNG isolated at St Mary's Hospital, London. We have found some evidence that there are factors influencing the transfer of plasmids. However, we have produced no evidence that can be used to explain the patterns seen amongst our strains. It seems probable that the peak seen around 1985 of strains with the 4.4 $\mathrm{MDa}$ plasmid without the conjugative plasmid belong to an epidemiological cluster of one $\mathrm{A} / \mathrm{S}$ class, Pro/IB-5/7. ${ }^{14}$ The difference between our two populations of strains may also be related to transmission within separate patient populations, but this requires more study.

We thank Professor C S F Easmon for his advice on the preparation of this manuscript.

Address for correspondence: Dr C A Ison, Department of Medical Microbiology, St Mary's Hospital Medical School, London W2 1PG, UK.

1 Phillips I. Beta-lactamase producing, penicillin resistant gonococcus. Lancet 1976;ii:656-7.

2 Percival A, Corkhill JE, Arya OP, et al. Penicillinase-producing gonococci in Liverpool. Lancet 1976;ii:1379-82.

3 Ashford WA, Golash RG, Hemming VA. Penicillinase-producing Neisseria gonorrhoeae. Lancet 1976;ii:657-8.

4 Centers for Disease Control. Penicillinase-producing Neisseria gonorrhoeae. MMWR 1976;25:261.

5 Perine PL, Thornsberry C, Schalla W, et al. Evidence for two distinct types of penicillinase-producing Neisseria gonorrhoeae. Lancet 1977; ii:993-5.

6 Embden JDA van, Klingeren B van, Dessens-Kroon $M$, Wijngaarden LJ van. Emergence in The Netherlands of penicillin- ase-producing gonococci carrying "Africa" plasmid in combination with transfer plasmid. Lancet 1981;i:938.

7 Roberts $M$, Falkow $S$. Conjugal transfer of $R$ plasmids in Neisseria gonorrhoeae. Nature 1977;266:630-1.

8 Yeung $\mathrm{K}-\mathrm{H}$, Dillon JR, Pauze M, Wallace E. A novel 4.9 kilobase plasmid associated with an outbreak of penicillinase producing Neisseria gonorrhoeae. J Infect Dis 1986;153: 1162-5.

9 Embden JDA van, Dessens-Kroon M, Klingeren B van. A new B-lactamase plasmid in Neisseria gonorrhoeae. J Antimicrob Chemother 1985;15:247-50.

10 Gouby A, Bourg G, Ramuz M. Previously undescribed 6.6 kilobase $\mathbf{R}$ Plasmid in penicillinase-producing Neisseria gonorrhoeae. Antimicrob Agents Chemother 1986;29:1095-7.

11 Brett M. A novel gonococcal B-lactamase plasmid. J Antimicrob Chemother 1989;23:653-4.

12 Jephcott AE. Epidemiology of resistance in Neisseria gonorrhoeae. J Antimicrob Chemother 1986;18 (suppl C):199-205.

13 Ison CA, Gedney J, Harris JRW, Easmon CSF. Penicillinase producing gonococci: a spent force? Genitourin Med 1986; 62:302-7.

14 Ison CA, Easmon CSF. Changes in penicillinae-producing Neisseria gonorrhoeae in London. J Med Microbiol 1989;30: $239-44$.

15 Woodford N, Bindayna KM, Easmon CSF, Ison CA. Associations between serotype and susceptibility to antibiotics of Neisseria gonorrhoeae. Genitourin Med 1989;65:86-91.

16 O'Callaghan CH, Morris A, Kirby SM, Shingler AH. Novel method for the detection of beta-lactamases by using a chromogenic cephalosporin substrate. Antimicrob Agents Chemother 1972;1:283-8.

17 Tam MR, Buchanan TM, Sandstrom EG, et al. Serological classification of Neisseria gonorrhoeae with monoclonal antibodies. Infect Immun 1982;36:1042-53.

18 Knapp JS, Tam MR, Nowinski RC, Holmes KK, Sandstrom EG. Serological classification of Neisseria gonorrhoeae with use of monoclonal antibodies to gonococcal outer membrane protein I. J Infect Dis 1984;150:44-8.

19 Copley CG, Egglestone SI. Auxotyping of Neisseria gonorrhoeae isolated in the United Kingdom. J Med Microbiol 1983; 16:295-302.

20 Birnboim HC, Doly J. A rapid alkaline extraction procedure for screening recombinant plasmid DNA. Nucleic Acid Res 1979;7:1513-23.

21 Genco CA, Knapp JS, Clark VL. Conjugation of plasmids of Neisseria gonorrhoeae to other Neisseria species: Potential reservoirs for the B-lactamase plasmid. J Infect Dis 1984;150:397-401.

22 Eisenstein BI, Sox T, Biswas G, Blackman E, Sparling PF. Conjugal transfer of the gonococcal penicillinase plasmid. Science 1977;195:998-1000.

23 Biswas GD, Blackman EY, Sparling PF. High-frequency conjugal transfer of a gonococcal penicillinase plasmid. J Bacteriol 1980;143:1318-24.

24 Blake MS, Gotschlich EC. Gonococcal membrane proteins: speculation on their role in pathogenesis. Prog Allergy 1983; 33:298-313.

25 Knapp JS, Holmes KK, Bonin P, Hook EW III. Epidemiology of gonorrhoea: distribution and temporal changes in auxotype/ serovar classes of Neisseria gonorrhoeae. Sex Transm Dis 1987;14:26-32

26 Dillon JR, Pauze M. Relationship between plasmid content and auxotype in Neisseria gonorrhoeae isolates. Infect Immun 1981;33:625-8.

27 Roberts M, Piot P, Falkow S. The ecology of gonococcal plasmids. J Gen Microbiol 1979;114:491-4.

28 Mavrommati L, Tzelepi E. Conjugal transfer of penicillin resistance plasmids to proline-citrulline-uracil dependent strains of Neisseria gonorrhoeae. J Antimicrob Chemother 1989;23:335-9.

29 Hagblom P, Korch C, Jonsson A-B, Normark S. Intragenic variation by site-specific recombination in the cryptic plasmid of Neisseria gonorrhoeae. J Bacteriol 1986;167:231-7.

30 Korch C, Hagblom P, Ohman $H$, Goransson $M$, Normark $S$. Cryptic plasmid of Neisseria gonorrhoeae: complete nucleotide sequence and genetic organisation. $J$ Bacteriol 1985;163: $430-8$.

31 Sarafian SK, Genco CA, Knapp JS. Transfer of gonococcal B lactamase plasmids to phenotypically different strains of Neisseria gonorrhoeae. Abstract E21. Proceedings of the Sixth International Pathogenic Neisseria Conference. Callaway Gardens, Atlanta, USA.

Accepted 1 February 1990 